\title{
The Cerdà Plan for the Expansion of Barcelona: A Model for Modern City Planning
}

\author{
Judith Urbano \\ PhD; Adjunct Professor, Escuela Tecnica Superior de \\ Arquitectura, Universitat Internacional de Catalunya
}

\begin{abstract}
Modern city planning started with the Industrial Revolution and the scientific advances of the 19th Century. At the time, Catalan engineer Idelfons Cerdà coined the word "urbanism" as a new and necessary science to deal with cities, having three major preocupations: hygiene, traffic, and equality. In this article, Judith Urbano discusses Cerda's plan for the expansion of Barcelona and why it is considered an icon of modern planning.
\end{abstract}

B

arcelona's 2,000 years of history is very apparent in its streetscape as buildings of different eras and architectural styles coexist side by side: Roman, Paleochristian, Romanesque, Gothic, Renaissance, Baroque, Neoclassical, Modernist, and Contemporary. But history is also evident in the city fabric, as development is revealed in the interplay of site and urban form. From Barcelona's foundation as a small Roman colony to the present, the city's many transformations responded to its increasingly important port; to its commercial and service dynamics in the regional, national, and international scenes; and to its population growth. This article discusses the importance of Ildefons Cerdà's visionary 19th century plan for the expansion of Barcelona that turned out to be one of the most revered international examples of modern planning and urban design.

\section{From Romans to Medieval Walls}

Like most cities built by the Romans in territories they conquered, Barcelona originated as a military camp at the end of the 1 st century BC. Shaped as an irregular octagon and protected by a surrounding wall with four guarded entrances, the city covered about 24 acres. Like all Roman settlements, its design was based on a regular orthogonal grid with two main streets: the cardo (running north to south) and the decumanus (running east to west). At the intersection of these two axes, the forum served as the administrative and religious center, including temples, shops, and municipal buildings. As in all Roman colonies, all other streets were based on the Roman army's basic unit, the legion, which sometimes included five thousand soldiers with different ranks and functions. Roman cities were rationally planned: They had to be practical in their use; and after retirement the legionaries were welcomed to settle in these newly founded towns.

It is difficult to know much about the first wall since it was rebuilt in the 4th century to be bigger and higher, including
76 defense towers (Puig \& Rodà, 2010). This new wall was built on top of the original footprint and materials from an old cemetery and other buildings located outside the protected perimeter were utilized in its construction to make it stronger. Remains from the Roman era can still be see in what is left from the wall in different parts of the city center, such as the gates to the decumanus and four Corinthian columns of the Augustus temple hidden in the courtyard of a medieval building. Outside the walls, in the ager, one can still find the ruins of the Roman cemetery and its austere tombs.

From the $1 \mathrm{st}$ to the 5 th centuries Barcelona slowly started to grow outside the Roman walls. Three monasteries and two churches in particular became foci for growth and new housing outside the walls, evidently with no planning. Opposite of the Roman period, streets were irregular and buildings were uncomfortable and unhealthy; there were no sewers, water supply or heating. Some of these new buildings were built onto the old Roman wall, incorporating the wall into their own construction.

By the 13th century the city-both inside and outside the original Roman fortification-was consolidated, and blocks of houses and streets had formed the medieval city. Buildings were mostly three-stories (42 to 48 feet) and many had arched passages in the ground floor to connect different spaces, sometimes between houses (González, 2010). The old Roman political and religious buildings inside the first wall were converted into new, medieval uses such as the Consell de Cent (Council of One Hundred), an assembly of leading citizens that selected five councillors with executive powers, the Romanesque Cathedral, and the Bishop's Palace.

By this time Barcelona had about 312 acres and a new 3.2-mile long wall was built to protect its inhabitants. To the south, in an area known as Raval or "the outskirts", some vegetable gardens and orchards were left outside the perimeter of the medieval wall. However, as the city continued to grow (possibly to 30,000 
people while Catalonia as a whole had 500,000 ) and it became important to protect these food sources in case of an attack or a siege, a new wall was built around the Raval in the 14th century. Some public buildings were made in this part of the city, including the Hospital de la Santa Creu and the Drassanes, the shipyard. Today, remains of the two medieval walls can be spotted throughout the city: in the access to the metro station of Plaça Catalunya at Pelai Street, in Pla del Teatre, in Carrer de les Flors and of course, in Portal de Santa Madrona. Also at that time a new gothic cathedral and other Romanesque churches inaugurated a new aesthetic and style, including Santa Maria del Mar and Santa Maria del Pi.

The cityscape changed significantly from Roman times; streets were narrow, dark and lacked ventilation. Although this was common in medieval European cities, in Barcelona the maintenance of the city walls impacted the city's organization, density, and the health of the residents leading to cholera epidemics by the mid 19th century. These city walls lasted until the 19th century when the population was significantly larger.

The industrial revolution -which in Spain began in Cataloniaadded to the unhealthy living conditions in Barcelona, as the new industries and factories inside the walls greatly affected the environment and living conditions. With the factories a new social class emerged, the proletariat, and a variety of social movements, strikes, unrest and demonstrations against the squalor and the terrible working and living condition they had to face. The first general strike occurred in 1855 and again during the revolt of the Tragic Week in 1909, monks and nuns were killed and several convents and churches were burned. On the other hand, the Industrial Revolution led the Catalan bourgeoisie to become aware of the need to invest in new factories, new technology, and eventually in the expansion of the city according to more modern principles. But before a new plan for expanding Barcelona could be chosen, the central government in Madrid had to agree to the demolishing of the medieval walls, which occurred from 1854 to 1856.

\section{The Plan for Barcelona's Eixample}

In 1854 a topographic plan of an area outside Barcelona's walls was commissioned to Ildefons Cerdà (1815-1875), a Catalan engineer who had been studying transportation issues in Barcelona since 1849. Because Cerdà had good relations with the central government in Madrid, he was commissioned by the Ministry of Public Works to study the extension of Barcelona and the renovation of the old city. But Barcelona's City Council decided to announce a competition for the plan on April 17, 1859 and asked Cerda to submit his work. The central government in Madrid made clear that they would keep the right to choose between the winner of the competition and Cerdà's plan (López, 2010).

\footnotetext{
${ }^{1}$ Eixample means expansion in Catalan.
}

The competition was won by Architect Antoni Rovira i Trias with a radial plan that was centered in the old historic town and incorporated the surrounding independent villages of Sants, Sarri and Gràcia. Radial plans were very popular in Europe at the time, such as the one during the Ringstrasse period in Vienna (1850 to 1857). However, this plan was rejected by the central Government of Madrid in 1860, who preferred Cerdà's.

Fortunately, Cerdà had deeply studied the living conditions inside Barcelona's medieval walls and he was well aware of the needs of a modern city. At that time city planning was looking to create a clear geometric street structure in order to organize spaces, functions, and movement.

Developed around some key elements, Cerdà's project was visionary in preparing Barcelona for later centuries (Figure 1). The city's expansion was organized into a regular orthogonal grid --reminding us of the planning of Greek and Roman cities-- for order and clarity, and into blocks measuring 113 meters square (370 feet). The blocks had buildings and sidewalks cut at a $45^{\circ}$ angle in all corners for higher visibility at street intersections, improving mobility and allowing for a small central plaza for services and complementary activities (shops, kiosks, toilets, etc.). With this design solution Cerdà had intersections take a prominent role in the city's structure (Figure 2).

Another important element of Cerdà's plan was the design of the streets at a time when carriages and horses were the predominant mode of the transport and the train was the most important innovation. A normal street in Barcelona's Eixample is 65 -feet wide (16-feet sidewalks at either side plus 32-feet for vehicular circulation) as Cerdà believed that a street had to serve four coaches at the same time and had to provide generous spaces to pedestrians (Grupo 2C, 2009). However, some avenues are wider because they connect important zones and provide connections through the city. Meridiana, the most important avenue connecting to the north; Gran Via, from east to west; and Diagonal, from north-east to south-west, are 164feet wide. Aragó varies from 98 to 131-feet and connects the city from west to east. Passeig de Gràcia is the widest avenue with 196-feet, because it is an artery linking Barcelona's old center to Gràcia, a village that soon would became part of the city (Busquets, 2009). This avenue became very popular at the end of 19th century and beginning of the 20th century time because it was closest to the center and provided a spacious area for families to stroll and socialize (Figure 3).

To provide for better living conditions, Cerdà knew that a green city was needed. The maximum building height was fixed at 72 feet and building footprints would be sited as to guarantee green public spaces on all blocks (Figure 4). This open recreational space would guarantee sun, light, and ventilation to all residential units. Additionally, he planned a large public park as a lung for the city in the Besós river area. Unfortunately, real estate pressures would eventually led to the abandonment of the original block concept and of the idea 


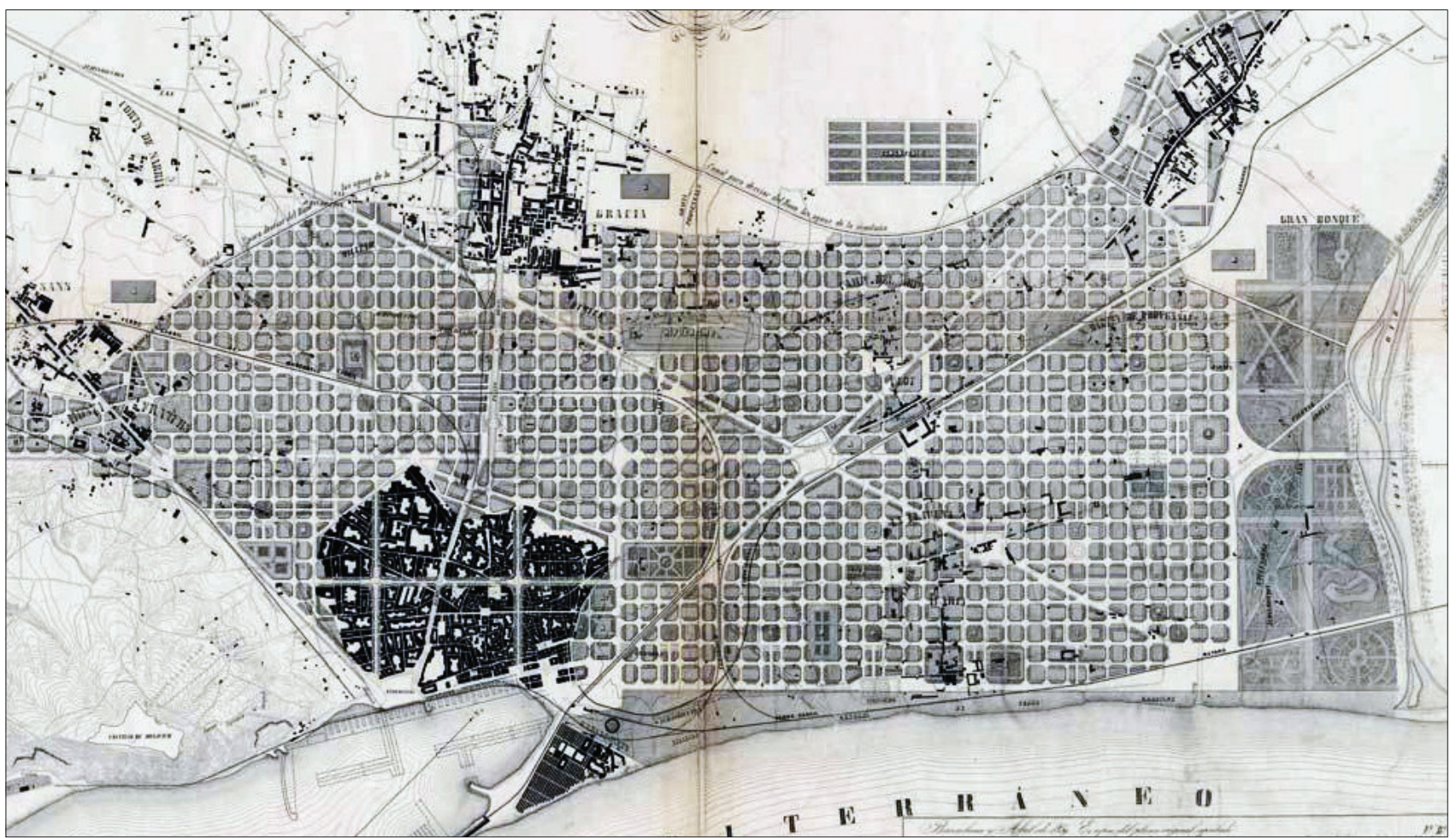

Figure 1: Cerdà's plan for Barcelona, 1859.

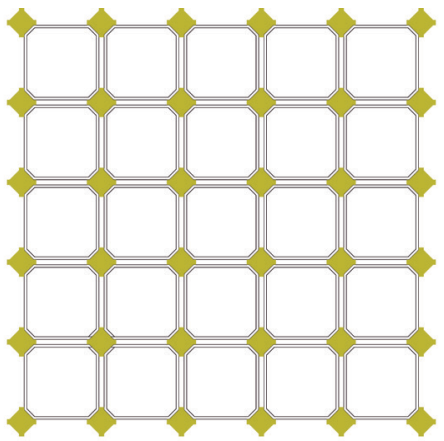

(courtesy of the City of Barcelona Historic Archives)

Figure 2: Barcelona's basic orthogonal street grid. In color, the space of influence of the chamfered corners. (Illustration by Guillem Carabi)

Figure 3: The popular Paseig de Gracia, with its landscaped median and chamfered corners, connects to the old center. (photo: Maria Gonzales; $h$ ttps://www.flickr.com/photos/ magoro/2111915341; retrieved 6/20/2015)

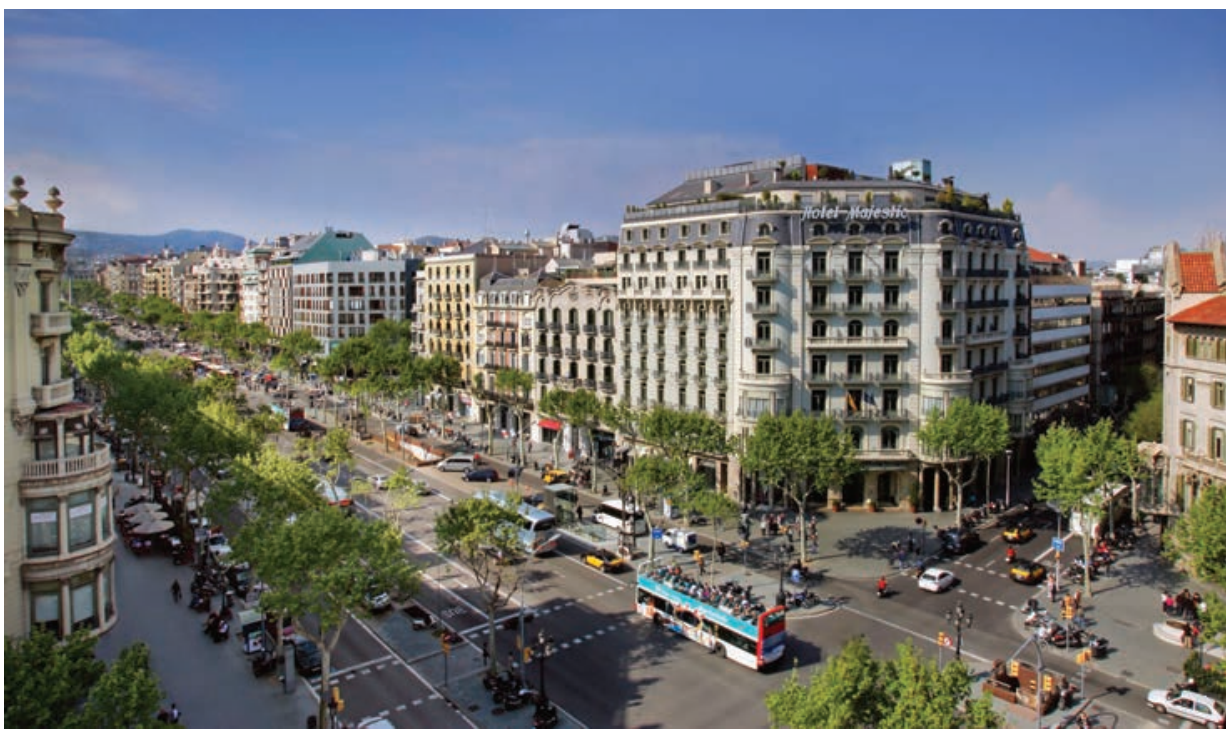




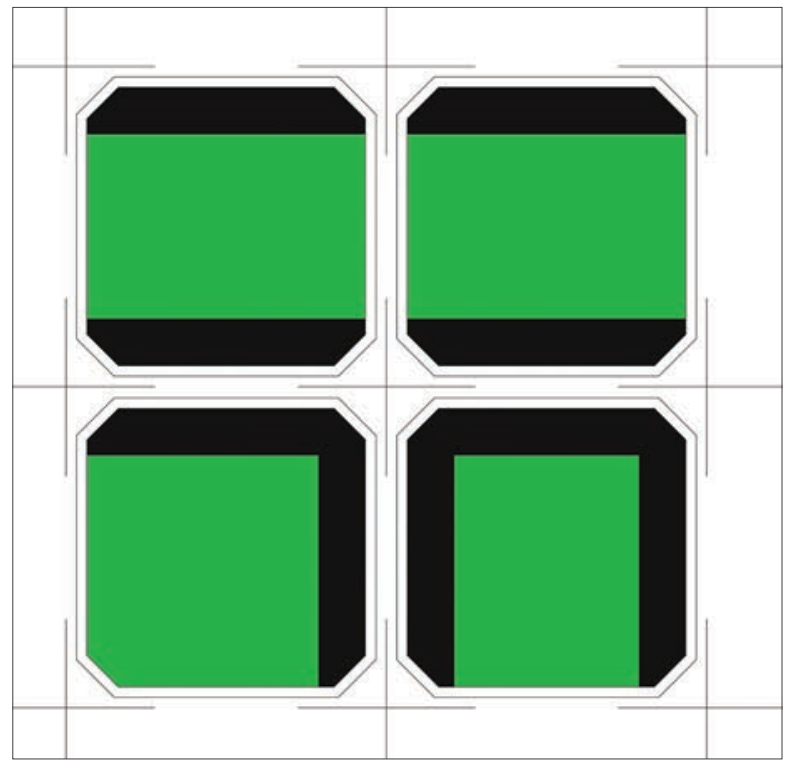

of the public spaces, and the park was never built. Developers built higher and the interior of the blocks got occupied by parking, shopping centers, and private quarters. Since 1987 the city, through public-private initiatives and incentives, has been promoting the conversion of the interior spaces of some blocks into gardens, playgrounds, and public facilities such as libraries and centers for the elderly.

Cerdà's plan divided the Eixample into sectors of twenty blocks each, providing them with public amenities such as a market, parks, schools and hospitals, providing homogeneity to Barcelona's functionality. He also planned for public transport, including the railway, what reaffirms his idea of progress and having the city as a center of the new industrial era.

Cerdà also planned for building types for different social classes. The most common type in the Eixample had the owner living on the first floor (which was called the principal since it was the most important) with the other floors subdivided into smaller apartments, usually two to a floor, and roof gardens. He also planned for wealthy families, a good example being the Passatge Permanyer, a passageway through a block with English-styled houses designed by Jeroni Granell in 1864. Most middle class and wealthy families chose the Eixample for their new homes and architects had a lot of work practicing different styles, from neoclassicism to art nouveau and the unique Barcelona's "modernisme" of Antonio Gaudí, Luis Domènech, Josep Puig, and others.

In 1897, in response to the city's growth, Barcelona's City Council annexed several surrounding villages. Gràcia, Sant Martí de Provençals, Sants, Sant Andreu de Palomar, Sant Gervasi de Cassoles and Les Corts had to give up their independence and became city quarters. But the intention of the plan was also to intervene in the Gothic Quarter, as the ancient city is known, that had been contained by the walls for so long, solving its

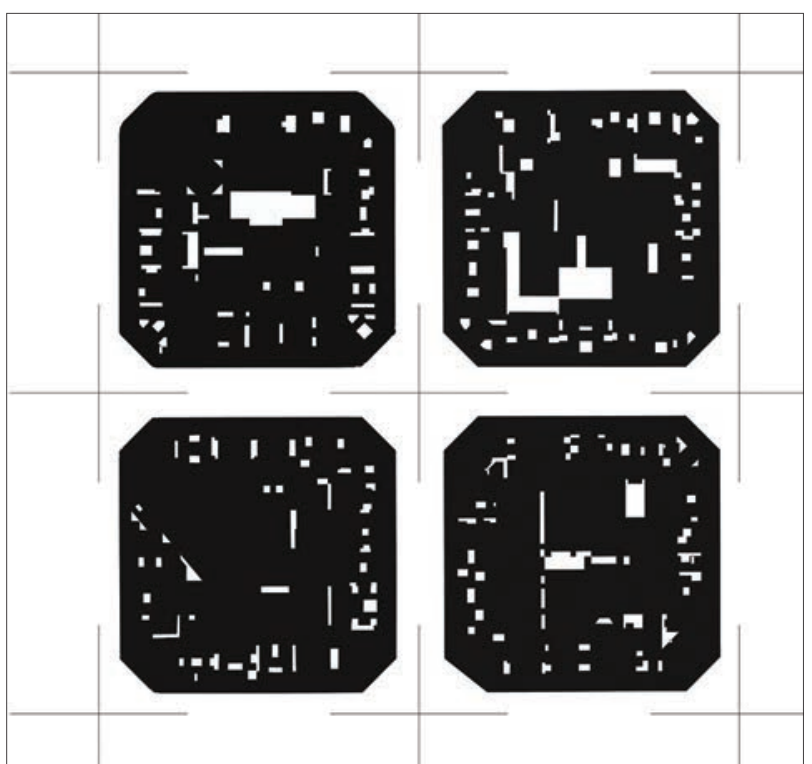

Figure 4. The blocks proposed by Cerdà included peripheral buildings and public green spaces (left) but were transformed over time due to speculation and privatization (right). (Case study: streets Roger de Llúria/Bruc/Girona and Gran Via/ Casp/Ausiàs Marc; Illustration by Guillem Carabí)

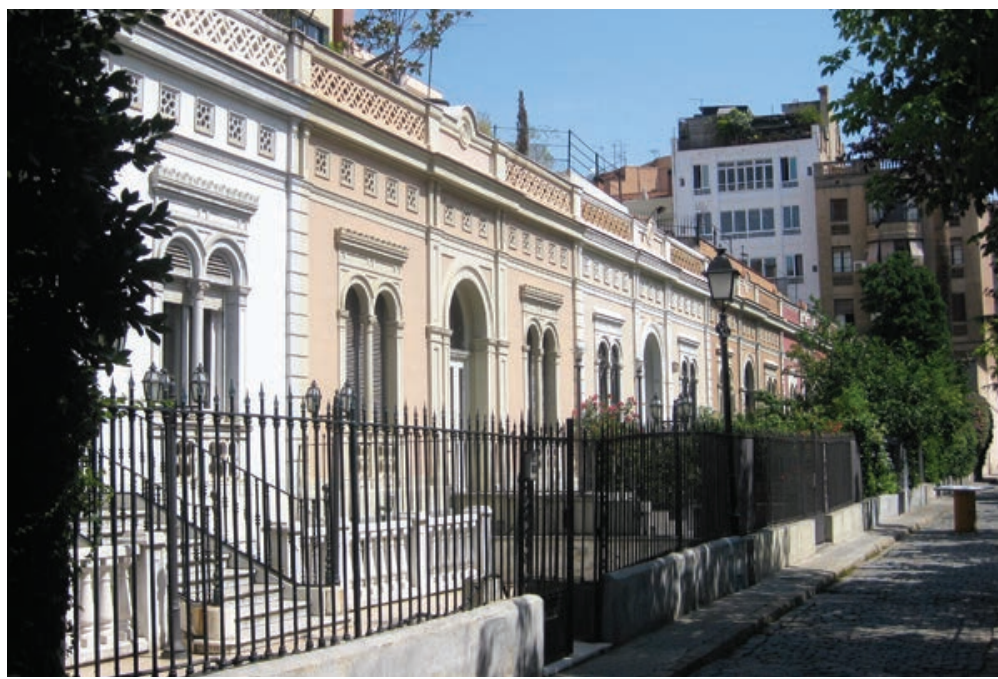

Figure 5. For Cerdà, the Eixample should serve different social classes and offer a variety of building types. English-style town-homes by Jeroni Granell, 1864. (photo by the author)

many problems. Cerdà proposed opening three new straight avenues: two connecting the new Eixample to the harbor, and the other cutting the old quarter at a perpendicular angle to them. However, the City Council adopted José Angel Baixeras's plan for the old quarter instead, which included Cerdà's three streets but added some other details. Work on the first of these avenues Via Laietana, started in 1908 and lasted until the 1950 s, but the other arteries were never built. 
